\title{
The Effect of Website Design Quality and Service Quality on Repurchase Intention in the E-commerce Industry: A Cross-Continental Analysis
}

\author{
Nicholas Wilson, ${ }^{a "}$ Keni Keni, ${ }^{\text {b }}$ and Pauline Henriette Pattyranie Tan ${ }^{c}$ \\ a Bunda Mulia University, Jakarta, Indonesia

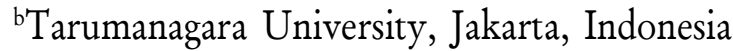 \\ cPelita Harapan University, Jakarta, Indonesia
}

\begin{abstract}
The purpose of this study is to examine the effect of website design quality and service quality on consumers' repurchase intention in the Asian, European, North and South American, and Australian e-commerce industry. This research implemented a survey method, in which a total of 1,000 questionnaires were distributed electronically to the respondents across five continents, of which a total of 869 were deemed usable. Out of 869 questionnaires, a total of 200 were collected from respondents living in Asia, 189 from respondents living in North and South America, 243 from respondents living in Europe, and 237 from respondents living in Australia. This research implemented the PLS-SEM method to analyze and generate findings from the data. Based on the results, it could be concluded that in Asia, Australia, and Europe, service quality played a more significant role in affecting repurchase intention, while website design quality played a more important role in affecting repurchase intention in the North and South American e-commerce industry. Furthermore, satisfaction positively mediated the relationships between website design quality, service quality and repurchase intention in all five continents.
\end{abstract}

Key words: cross-continental study; customer satisfaction; repurchase intention; service quality; website design quality; worldwide e-commerce industry

JEL classification: M160; M300; M310 


\section{Introduction}

The development of the internet in recent years has changed the way people are doing business because they are starting to do it digitally as compared conducting business in a traditional way. Known as e-commerce, the rising trend of this new way of doing business has swept all around the globe for around a decade, and there has been a steady increase in the number of sales generated by this industry. The rising popularity of e-commerce might be explained by underlining the advantage that e-commerce has as compared to traditional commerce. In traditional commerce, sellers and buyers need to meet each other at the same place, conduct a negotiation, and make a transaction on the spot when both parties have agreed about the price. Meanwhile, such a practice won't happen with e-commerce as buyers and sellers don't need to meet each other. Instead, they meet through a website which acts as an intermediary which connects both parties and bridges the transaction. Therefore, the buyers can buy a product/services from their homes, and the sellers can conduct their business even though they do not have a place/store. With regard to this, it could be stated that, while traditional commerce requires the seller to have a physical store and also requires the buyer to come to the store, e-commerce eliminates these requirements. Thus, the rising popularity of ecommerce might be attributed to these advantages, which include it's simplicity, timeliness, efficiency, and how it can reduce the costs incurred for both the seller and buyer (Wilson and Christella 2019).

In terms of e-commerce, as with other industries, the importance for business of repurchase intention has been underlined by several researchers or authors (Wilson et al. 2018; Wilson and Keni 2018; Wilson 2018; Wilson and Christella 2019; Bernarto et al. 2019). Also known as the factor which could assess customer's loyalty, establishing repurchase intention in consumers' minds is an important task which each company has to do in order to be successful. When a customer has an intention to make purchases again, whether it is the same product/service or a different one from the same company, it is an advantage for the company, as there's a low chance that the customer will purchase the product/service from another company in the same industry. Moreover, several researchers have underlined the connection between customer loyalty and a company's success because a company having as many loyal customers as possible can become a key step in achieving success in the industry as the company can indirectly retain the customers (Lee et al. 2009).

Although there are many factors which may affect consumer's repurchase intention, website design quality and service quality are seen as important ones which can contribute to the formation of repurchase intention in consumers' mind in the field of e-commerce or internet marketing. In terms of website design quality, Zhou et al. (2009) state that, for a website to be classified as having a great design, it shouldn't only be visually attractive to users, but should also have a great navigational function in order to enable potential customers to explore the website more thoroughly and to prevent them encountering any difficulties doing so. Great visual aspects (great color combination, great layout, appealing font size) act as factors which will attract the general public to come and visit the website. After they come 
and visit the website, the technical aspects of the website (great layout, products which are presented attractively, great navigational function) will determine whether potential customers will leave or continue exploring the website. When people decide to continue exploring the website, not only does it mean that the overall design of the website is great, but it also increases the chance of customers making purchases using the website. Therefore, website design quality plays a major role in both attracting and encouraging customers to purchase a product/service through the site. Just as important as website design quality, service quality also plays an important role in determining consumers' repurchase intention. Defined as customers' assessment of services provided by a company, and whether or not the quality of the services they receive exceeds their expectations, service quality has been heralded as one of the most important factors in determining the survivability of a company in the industry (Parasuraman et al. 1985; Chowdary and Prakash 2007).

Furthermore, service quality is also understood to be an important factor in determining the success or failure of a company conducting business in the e-commerce industry (Santos 2003). With e-commerce, sellers and buyers don't meet up with each other in a market, so transactions are conducted virtually over a network. Therefore, the buyers can't touch, smell, or try the product until it arrives at their address and they just hope that the product that they ordered matches with the description and the picture posted on the ecommerce website. In terms of this, when the product fails to live up to expectations (its characteristics don't match the description provided on the website), buyers will be disappointed with the company's service because it will have failed to fulfill the "promise" to send the product with the description provided on the website. The other aspects of service quality, such as the speed of delivery, timeliness, and customer service efforts to help resolve customers' problems, can also play a great role in determining whether the companies value theirs customers or not (Budiyanti and Patiro 2018; Wilson and Christella 2019). Bad or negative service quality can be perceived as a sign that the company doesn't value or it "neglects" its customers, and vice versa.

Previous research by Zhou et al. (2009) in the Chinese e-commerce industry finds that service quality plays a greater role in affecting consumers' repurchase intention compared to website design quality where these relationships were mediated by customer satisfaction and customer satisfaction. Moreover, previous research conducted by Wilson and Keni (2018) in the Indonesian e-commerce industry provides similar results that show both website design quality and service quality have a positive and significant effect on consumers' repurchase intention, both directly and indirectly through trust. Furthermore, this research also concludes that service quality plays a greater role in affecting consumers' repurchase intention as compared to website design quality. Another piece of research by Bernarto et al. (2019), also in the Indonesian e-commerce industry, has also generated the same results in which service quality has a more significant effect on consumers' repurchase intention as compared to it counterparts, which is website design quality. With regard to all of these research, Zhou et al. (2009), Wilson and Keni (2018), and Bernarto et al. 
(2019) state that one of the limitations which exist in all of this research is the fact that the results of those aforementioned studies might not be generalizable since all were conducted by using only Chinese and Indonesian respondents as the samples for the studies. Bearing in mind the limitations presented by Zhou et al. (2009), Wilson and Keni (2018), and Bernarto et al. (2019), this research has been conducted in order to fill these gaps and it intends to increase the generalizability of both models by analyzing the effect of website design quality and service quality on consumers' repurchase intention in the e-commerce industry across five continents, which are Asia, Australia, North and South America, and Europe.

Moreover, this research was also conducted in order to know the effect of website design quality and service quality on consumers' repurchase intention in the worldwide e-commerce industry in a simultaneous manner, in order to provide both theoretical and practical insights to academicians, business managers, and companies which involve or run their business in the e-commerce industry all around the world. Therefore, the authors believe that the results of this research could help e-commerce companies all around the world to craft, implement or execute the best strategy intended to better serve the customers, which could be beneficial for the companies' longevity and their strategic position in the market, compared to their competitors. Furthermore, with regard to the originality of this research, to the author's knowledge, this is the first research ever which attempted to uncover the effect of website design quality and service quality on consumers' repurchase intention across all four (4) continents simultaneously.

\section{Literature Review and Hypotheses}

\section{Website Design Quality}

A website's design quality can be defined as its quality assessed in terms of the navigational system and the appearance of the website (McKnight et al. 2002; Cyr et al. 2008; Zhou et al. 2009; Wilson and Keni 2018; Bernarto et al. 2019). In the context of the e-commerce industry, website design quality plays a very important role in determining a company's success. This is not solely because the website can play important roles in establishing and implying satisfaction on the part of customers (Corbitt et al. 2003), but also because a website acts as a communication tool which acts as a "bridge" between the seller and the buyer. Unlike with traditional commerce, where a company or seller can directly meet and communicate with a potential buyer through direct or face-to-face interaction, companies which are conducting their business in the digital environment don't have a direct interaction with customers or buyers. Instead, the interaction between both parties will be fully mediated by the existence of a website.

Through the website, a seller can communicate with a buyer in a indirect manner whereby the seller can post information about the products or services that they want to sell, while at the same time, the buyer will open the website and browse and look at the product/service posted by the seller, and determine whether or not to buy it. In this case, if the buyer feels that the description or the specifications of the product had been described unclearly, and they would like to ask the seller about it, they can ask the seller through the web chat 
service that is usually provided by the website. Therefore, based on the explanation above, it can be stated that the design quality of a website can play an important role in establishing the relationship between the buyer and the seller, since buyer won't experience any difficulties in contacting the seller or company if they feel unsure about the product or service sold on the website.

\section{Service Quality}

Service quality can be defined as a comparison between customers' expectation of the service that they will get from a company and the actual service or performance that the company provides them with (Yousapronpaiboon 2014). Moreover, Samoszuk (2011) also defines service quality as a measurement of the service given by a company in terms of whether the actual quality of the service provided or presented by a company is less than, matches, or exceeds a customer's actual expectations regarding that service. On the other hand, service quality could also be defined as a comparison between customer's perceptions about the service that a company will provide and their own expectation regarding the actual service that they get (Oliver 1997). In terms of service quality, if a customer's experience of the service provided by the company is better than the expectation that he or she had, it can be said that the service quality of that company is considered to be excellent. On the other hand, if the perception that customers have of the actual service quality is equal to the expectation that they had previously, the service quality of the company can be considered to be good, and if the actual perception that a customer has regarding the company's service quality is actually less than or lower than the expectation that he or she has regarding the service, the service quality of a company can be considered to be bad.

In the past decade, the importance of the concept of service quality in the field of marketing around the world has increased and many marketers and companies are trying hard to be able to provide excellent service quality to all of their customers at all times (Oliver 1993). However, in the current era, a company's highest priority is to fully understand the impact that service quality has on its profits and other financial outcomes which it can benefit from (Greising 1994; Rust et al. 1995; Wilson 2018; Wilson and Keni 2018). This is the reason of why, nowadays, many companies are trying hard to serve and provide their customers with the best service quality that they can give. Moreover, companies that can provide and deliver a service that is perceived as "High Quality" are normally those which have a greater market share, higher return on investment, and higher asset turnover compared to other companies whose services are perceived as a "Low Quality" by people and customers (Kim et al. 2004). This is why, many companies are constantly attempting to improve the quality of service they provide to their customers (Ueltschy et al. 2007).

Parasuraman et al. (1991) further state that, in order to enhance or improve its service quality more efficiently and accurately, a company can use technologies which improve its service and, in the long run, such improvement can also increase the market demand for the company's service. Moreover, in terms of conducting business in the current era, in which technology is rapidly evolving and has changed the way people are conducting business, 
service quality has become an even more critical factor for a company in retaining and attracting its customers and preventing them from shifting to their competitors (Jiang and Rosenbloom 2005).

\section{Customer Satisfaction}

Hansemark and Albinsson (2004) define customer satisfaction as an overall attitude that customers have towards a product/service provider whereby they can show their emotional reaction when they face a situation in which there's a difference between what they expect to receive and what they actually receive, with regard to the fulfillment of consumer's needs or desire.

In terms of building customer satisfaction, Mohsan et al. (2011), state that there are several factors which can affect customer satisfaction, some of which are: friendliness, courtesy, helpfulness, and knowledgeability on the part of employees; billing accuracy, clarity and timeliness; competitive pricing; service quality; good value; and the speed of the service being provided to the consumers. Bearing in mind the factors stated above, it is important for a company to be able to maximize its potential by improving its business based on the factors above which, in the long run, if all of them are developed well, should lead to a company or organization being able to fully satisfy customers' needs and wants (Mohsan et al. 2011). On the other hand, Singh (2006) added that satisfied customers are really important to an organization, since such customers will become the main factor which can make a business successful. Moreover, satisfaction on the part of customers will lead them to repeat their purchase and will also encourage them to spread positive messages about a company by word of mouth.

Moreover, being able to fully satisfy customers' needs and wants at any time is an important thing a company or organization should remember (Wilson 2018). This is mainly because customer satisfaction has a positive impact on a company's profitability and if there are more customers who feel satisfied with the performance of the product or service, there's a strong possibility that those customers will engage in another purchasing activity with the company, thus positively affecting the company's profitability, either in the shortto-medium term, or in the long term (Wilson and Keni 2018; Wilson and Makmud 2018). On the other hand, if customers are less satisfied with the performance of a product or services provided by a company or an organization, the company's profitability is likely to decline. Therefore, it is really important for a company to be able to fully satisfy its customers, since such an ability is vital for that company to be able to have competitive advantages and strive to be the best in a highly competitive industry (Ganiyu et al. 2012; Japutra et al. 2015; Wilson and Keni 2018).

\section{Repurchase Intention}

Repurchase intention is often perceived as one of the factors which can measure a customer's loyalty toward a company. Therefore, it is important for a company to formulate and implement several strategies in order to ensure that its customers engage in repurchase behavior (Chinomona and Dubihlela 2014; Wilson and Keni 2018; Wilson 2018; Bernarto et al. 2019). Moreover, Cronin et al. (2000) further refer to consumers' repurchase in- 
tention as an important aspect which generally determines the success of a company or organization in a business. Furthermore, as time has gone by, the market has become filled with more and more companies which has intensified the competition between them. Thus, many companies are trying hard to preserve their customers by persuading them to engage in repurchase activity rather than attracting new customers, which could cost a company a lot of money (Fornell 1992; Kitchakhorn 2013). This statement is supported by Rosenberg and Czepiel (1984), who find that a company's effort to acquire a new customer can cost the company approximately "six times" more than the cost the company will bear by keeping a current or existing customer. Schiffman and Kanuk (2007) and Wilson (2018) stated that although there have been some studies in the area of customers' repurchase behavior and intention, all of these have actually reached the same conclusion that customers' repurchase intention can generate some economical advantages for a company (Chinomona and Dubihlela 2014).

\section{Hypotheses Formulation}

\section{The Effect of Website Design Quality toward Customer Satisfaction}

Website design quality plays an important role in the formation of the image of an online store conducting e-commerce and, if the image can create a "good" first impression in customers' minds, it can lead to customer satisfaction ( $\mathrm{Oh}$ et al. 2008). Moreover, another study conducted by Eroglu et al. 2003) also explains the influence that website design effectiveness has on consumer responses, judgement, and various other consumers' behavioral intentions. These findings are supported by another study by (Ha and Im 2012), which revealed that both customers' response and cognitive judgment are really important and act as a requirement for a company to create customer satisfaction. Additionally, it is also determined that the design elements of a website, such as color and music, have significantly affect a customer's levels of pleasure, satisfaction, and arousal (Wu et al. 2008; Ha and Im 2012).

Further studies by Zviran et al. (2005), Van Riel et al. (2004), Zeithaml et al. (2002), Chang and Chen (2008), and Wilson and Keni (2018) also reveal that website design quality has different and subjective factors which can affect overall customer satisfaction with the website. Furthermore, Jeong et al. (2003) and Wilson and Keni (2018) also state that satisfaction turns out to have important consequences which can be affected by the information provided on a website. Based on the literature and the results of the previous research, the author posits the first hypothesis (H1) and the second hypothesis (H2) as follows:

H1: Website design quality has a positive effect on customer satisfaction

H2 : Website design quality has a positive effect on repurchase intention through customer satisfaction 


\section{The Effect of Service Quality toward Customer Satisfaction}

Magi and Julander (1996), and Bernarto et al. (2019) state that customer satisfaction and service quality are two incredibly important variables for a company since both have been proven to help improve the overall performance of an organization. Additionally, service quality actually acts as a determinant of customer satisfaction because it is based on customers' experience of certain services that they receive from the provider and the outcome of the services provided by the provider is actually the quality of the service of the organization (Cronin and Taylor 1992; Agbor 2011). Moreover, customers expect to derive a maximum level of satisfaction from the products or services that they purchase from a company which serves them (Agbor 2011). Furthermore, building a strong and permanent customer relationship is an important thing a company needs to do in order to become successful in the market (Agbor 2011; Bernarto et al. 2019).

Furthermore, Kotler et al. (2002), Wilson (2018) and Wilson and Keni (2018) also state that, to be able to deliver value to customers that is superior that of competitors, a company should build a long-lasting relationship with its customers. Moreover, Kotler and Keller (2009) further argue that the feedback that customers give about the products or services that they buy and use, and the level of satisfaction that they derive from purchasing and using the products, can be used as a tools to assess whether the service quality of an organization is perceived by customers as good or not. Sureshchandar et al. (2003) further found out that there's a strong relationships between company's service quality and customer satisfaction. Moreover, a study conducted by Spreng and Mackoy (1996) also shows that a company's service quality will lead to customer satisfaction. Furthermore, findings by Ribbink et al. (2004) and Bernarto et al. (2019) also show that service quality positively affects customer satisfaction in the e-commerce business.

Moreover, another study in the field of retailing also finds that customer satisfaction and attitude with department stores is influenced by the service quality of the stores. (Sivadas and Baker-Prewitt 2000). On the other hand, another piece of research by Negi (2009) also finds that tangibles, empathy and assurance, which together are known as a part of SERVQUAL, which is widely used to measure service quality, are relevant factors which determine customer satisfaction. Another study by Gera (2011) also finds that customer satisfaction is significantly affected by the quality of a service offered or given by a company or organization. Furthermore, Agbor (2011) and Bernarto et al. (2019) state that the service quality dimension positively affect customer satisfaction only if customers feel that they are satisfied, and the reason for their satisfaction is the service quality of a company. Based on the literature and the results of previous research, the author posits the third (H3) and the fourth hypothesis (H4) as follows:

H3: Service quality has a positive effect on customer satisfaction.

H4 : Service quality bas a positive effect on repurchase intention through customer satisfaction. 


\section{The Effect of Customer Satisfaction on Repurchase Intention}

A previous study by Chinomona and Sandada (2013) finds that customer satisfaction has a positive effect on customer loyalty and it also positively affects customer repurchase intention in the South African retailing industry. Their results are supported by another piece of research conducted by Jia et al. (2014) in the electronic commerce industry which shows that there is a positive relationship between satisfaction and repurchase intention. Another similar study done by Aksoy et al. (2011) on the U.S. stock market performance shows that customer satisfaction positively affects repurchase intention and this relationship can lead to the improvement of the stock market performance in the U.S. Further research regarding the relationship between customer satisfaction and repurchase intention of soft drink consumers in Pakistan also shows that customer satisfaction has a positive effect on customer repurchase intention (Hussain and Rizwan. 2014).

Furthermore, another study by $\mathrm{He}$ and Song (2008) on the tourism industry

\section{Figure 1. Research Model}

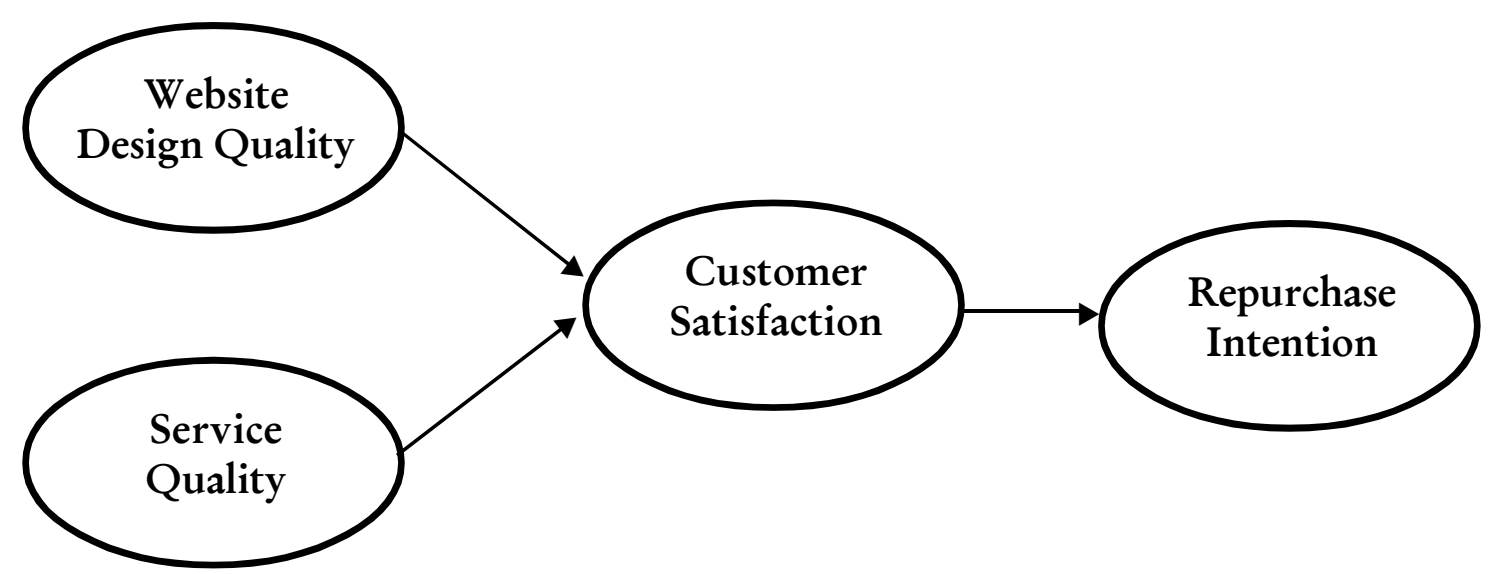

shows that customer satisfaction with regard to the services positively affects repurchase intention. Further research by A mini and Akbari (2014) on the relationship between customer satisfaction and online repurchase intention also finds that customer satisfaction positively affects customer repurchase intention on websites. Additionally, another piece of research by Lee et al. (2009) shows that, through two moderating variables, which are computer self-efficacy and computer anxiety, customer satisfaction significantly affects repurchase intention. Another study conducted by Lin and Lekhawipat (2014) further reveals that customers with high levels of satisfaction are more likely to engage in repurchase activity with a company rather than customers with lower levels of satisfaction with a company. Other findings by Sunyasanoa et al. (2013) show that consumer satisfaction has a positive and significant relationship on consumer repurchase intention in Thailand. However, previous research by Bernarto et al. (2019) has generated contradictory results with customer satisfaction not having a positive impact on consumers' repurchase intention in the Indonesian e-commerce market. 
Another piece of research done by Zboja and Voorhees (2006), about the effect of customer satisfaction on repurchase intention in the retailing industry, shows that there is indeed a direct and positive relationship between customer satisfaction and repurchase intention, while Upamannyu et al. (2015) also state that an increase in satisfaction will increase consumers' repurchase intention with regard to the company. Based on this literature and the results of previous research, the author posits the fifth hypothesis (H5) as shown in Figure 1.

H5: Customer satisfaction has a positive effect on repurchase intention.

\section{Methods}

This research utilizes the survey method therefore questionnaires have been used as the instruments to collect all of the data needed. There are two parts to the questionnaire: the first part contains the questions regarding the demographics of the respondents; the second part contains a total of 34 items which represent all 4 variables analyzed in this research. Out of the 34 items, 4 items represent variables related to website design quality, 20 items represent variables related to service quality, 5 items represent variables related to customer satisfaction, and 5 items represent variables related to repurchase intention. Variables related to service quality have been measured using SERVQUAL dimensions (reliability, responsiveness, assurance, tangibles, and empathy), where, out of 20 items which represent variables related to service quality, each dimension is represented by four items. All items used to measure service quality have been adapted from Gefen (2002). Meanwhile, all Items of website design quality have been adapted from Zhou et al. (2009), while all items representing customer satisfaction have been adapted from Zhou et al. (2009) and Fang et al. (2014). Items representing consumer's repurchase intention have been adapted from Zhou et al. (2009). All items have been modified in order to ensure that all items conform to the topic of this research. Furthermore, regarding the scale of measurement of this research, a 5-Point Likert Scale was used whereby each respondent is asked to give their response regarding each statement presented on the second part of this questionnaire, and this consists of a " 1 " reflecting their strong disagreement with the statement, a " 2 " reflecting their disagreement with the statement, a " 3 " reflecting that they neither agree nor disagree with the statement, a "4" reflecting their agreement with the statement, and a " 5 " reflecting their strong agreement with the statement.

Before the main research was conducted, a pretest was conducted in order to ensure the clarity of the statements appearing on the questionnaire. Malhotra (2007) states that a questionnaire should be pretested adequately before it can be used of the actual survey. Moreover, the pretest study was conducted in order to ensure that all of the items on the questionnaire truly represent and measure each variable. A total of 120 respondents originating from the five continents (Asia, Australia, North and South American, and Europe), and who were drawn from the same population and shared the same characteristics as the respondents, participated in the pretest. Questionnaires were electronically distributed to the pretest participants and all were returned, thus ensuring the 100 percent response rate. Participants were also asked 
to add some notes on the questionnaires if there were some difficulties they encountered when they read and filled them out. After all of the data were collected, validity and reliability tests were conducted first in order to ensure that all of the data are valid and reliable, and the questionnaire could be used in the actual research. After conducting both tests, it was deemed that all items were valid and reliable, thus ensuring that none needed to be omitted. Moreover, several modifications were made to the wording of the questionnaire based on the participants' input. After these modifications, it was concluded that the questionnaire could be used in the actual research.

A total of 1,000 respondents participated in this research and 250 questionnaires were distributed electronically to those living on each continent (with 250 being sent to North and South America which has been treated as one region). Regarding the criteria of the respondents participating in this research, all the selected respondents had engaged in purchasing activity through e-commerce websites in their respective regions during the last six months. Furthermore, the sampling method used in this research was purposive sampling in order to ensure the objectivity of the research because all respondents who participated in this research had to fulfill the criteria set beforehand and they had to have engaged in purchasing activity on any e-commerce website in the countries where they lived in the six months before the questionnaire was filled out.

Regarding the decision to generate samples from five continents - namely the Asian, Australian, European, and the North and South American continentsthe author contends that the invention, development, and growth of the e-com- merce industry has taken the world by storm and so there are a lot of e-commerce companies that have been established in many countries which are located within the boundaries of those continents. On the other hand, a lot of large e-commerce companies have established branches in various countries and markets across the globe, further suggesting and indicating that the industry has been growing and developing into one of the fastest and most-promising ones of the $21^{\text {st }}$ century. Therefore, the author has developed a very strong interest in uncovering the effect of website design quality and service quality on consumers' repurchase intention, not only on one continent, but on the other continents as well. Therefore, one of the author's main objectives in executing this study is to discover the effect of the variables studied in this research on a worldwide basis. So, the author has decided to select and involve respondents are living on those continents, since the e-commerce industry has been seen as being one of the most developed and fastest-growing industries in the aforementioned five continents.

After distributing 1,000 questionnaires, 869 were filled out and returned thus generating an overall response rate of 86.9 percent. From the Asian continent, a total of 200 out of 250 questionnaires were filled out and returned, a response rate of 80 percent. A total of 237 out of 250 questionnaires distributed in Australia were filled and returned, a response rate of 94.8 percent. A total 189 out of 250 questionnaires (75.6\%) distributed in North and South America were filled and returned. Lastly, A total 243 out of 250 questionnaires (97.2\%) distributed in Europe were filled out and returned. After collecting and conducting a pilot analysis on the data, a total 
of 869 responses were confirmed to be usable and ready to be analyzed. The data from each continent have been analyzed separately, thus generating a total of four sets of analysis in this research (North and South America were analyzed together). In order to analyze the data and generate the findings of this research, the approach used and implemented was partial least squaresstructural equation modeling (PLS-SEM) .

\section{Data Analyses and Hypotheses Testing}

All data collected from the questionnaires have been processed using the Partial Least Squares-Structural Equation Modeling (PLS-SEM) method by using SmartPLS 3.2.7 software. In this research, data which are collected from each continent will be analyzed separately from each other, meaning that a total of four results (one for each continent with North and South America treated as one continent) will be generated by this research.

\section{Asian Continent}

Out of the 250 questionnaires distributed to the respondents living on the Asian continent, a total of 200 were filled out and returned, thus generating a response rate of 80 percent. After further analysis, it is concluded that all questionnaires were usable, thus enabling the data to be processed in this research. In terms of the profile of the respondents, 200 respondents of those participating in this research originat from eight countries located on the Asian continent, namely China, Indonesia, Malaysia, Singapore, Iran, South Korea, Japan, and Hong Kong. In terms of the respondents' gender, a total of 127 (63.5\%) were male, while the remaining $73(36.5 \%)$ were female. Furthermore, a total of 189 respondents engaged in purchasing activities between eight and fourteen times through an e-commerce website during the last six months, while a total of 11 respondents engaged in purchasing activities more than 15 times through an e-commerce website during the last six months.

Before formulating the hypotheses in this research, several assessments need to be conducted beforehand to ensure that the model is valid and reliable. Those were an assessment of the service quality dimensions, outer model assessment, and the inner model assessment. First of all, an assessment of the service quality dimensions and outer model analysis need to be conducted in order to determine whether all dimensions measuring service quality (reliability, responsiveness, assurance, tangibles, and empathy) can really measure variable service quality. In order to conduct these assessments, several criteria need to be fulfilled in order to determine that all dimensions can explain service quality variables, and to determine that all dimensions and variables have fulfilled all of validity and reliability criteria set in this research. Those criteria are as follows: the factor loadings value of each item should exceeded 0.50 (Barclay and Thompson 1995; Chin 1998; Wilson, 2018); the AVE of each dimension should exceeded 0.50 as suggested by Hair et al. (2011) and Wilson (2018); the composite reliability of each dimension should exceed the cut-off value of 0.70 as suggested by Henseler et al. (2009) and Ebert (2010); the value of square root of AVE of each latent construct should be higher than the construct's highest squared correlation with any other latent construct (discriminant validity analysis/fornell-larcker crite- 
rion) as suggested by Hair et al. (2011); and the t-value of each dimensions should exceed the cut-off value of 1.96 in order to confirm that each dimension can represent and explain variable service quality well.

Based on the results of the data analysis presented on Tables 1,2,3, and 4, it can be concluded that all dimensions, indicators and variables have fulfilled all of the criteria set out in this study. Therefore, the inner model analysis can be conducted in order to determine the relationships between variables studied in this research.

After completing both the analysis of the service quality dimensions and the outer model analysis, the inner model analysis is conducted on the data and the model in order to determine the relationship between variables. Furthermore, mediating analysis is also conducted in this research in order to determine whether variable customer satisfaction does not mediate, partially mediates, or fully mediates the relationship between website design quality and repurchase intention, and between service quality and repurchase intention. Moreover, data generated from the inner model analysis will be used as a benchmark to determine whether the hypotheses posited in this research are supported or rejected. Based on the results generated during the PLS-SEM analysis, it can be concluded that both website design quality ( $\mathrm{t}$-value $=$ $3.418)$ and service quality $(\mathrm{t}$-value $=5.598)$ have a positive effect on repurchase inten- tion, while customer satisfaction partially mediates the effect of website design quality $(\mathrm{t}$-value $=3.581)$ and service quality $(\mathrm{t}$ value $=6.174)$ on repurchase intention. Furthermore, the results of the r-squared value generated by this analysis, show that variable customer satisfaction and repurchase intention have a r-squared value of 0.556 and 0.697 respectively. Based on these results, it can be concluded that variable customer satisfaction is explained by the variables of website design quality and service quality by 55.6 percent, while variable repurchase intention is explained by the variables discussed in this research by 69.7 percent.

Furthermore, path coefficient analysis has been conducted not only in order to know the relationship between variables, but also to know whether the hypotheses proposed in this research were supported or rejected. The results generated by the path coefficient analysis show that the $t$-value of all hypotheses exceed the cut-off $t$-value of 1.96. Therefore, based on these results, it can also be well-concluded that on the Asian continent, all hypotheses in this research are supported. After conducting the analysis on the data gathered from the respondents living on the Asian continent, the author has then proceeded with the analysis of the data gathered from the respondents living on the Australian continent. 
Table 1. Service Quality Dimensions and the Outer Model Analysis (Asian Continent)

\begin{tabular}{|c|c|c|c|c|}
\hline Dimensions & Items & $\begin{array}{c}\text { Factor } \\
\text { Loadings }\end{array}$ & AVE & Composite Reliability \\
\hline Reliability & $\begin{array}{l}\text { REL1 } \\
\text { REL2 } \\
\text { REL3 } \\
\text { REL4 }\end{array}$ & $\begin{array}{l}0.780 \\
0.679 \\
0.820 \\
0.778\end{array}$ & 0.569 & 0.757 \\
\hline Responsiveness & $\begin{array}{l}\text { RES1 } \\
\text { RES2 } \\
\text { RES3 } \\
\text { RES4 }\end{array}$ & $\begin{array}{l}0.756 \\
0.808 \\
0.593 \\
0.726\end{array}$ & 0.577 & 0.771 \\
\hline Assurance & $\begin{array}{l}\text { ASS1 } \\
\text { ASS2 } \\
\text { ASS3 } \\
\text { ASS4 }\end{array}$ & $\begin{array}{l}0.718 \\
0.892 \\
0.866 \\
0.813\end{array}$ & 0.625 & 0.843 \\
\hline Tangible & $\begin{array}{l}\text { TAN1 } \\
\text { TAN2 } \\
\text { TAN3 } \\
\text { TAN4 }\end{array}$ & $\begin{array}{l}0.760 \\
0.749 \\
0.607 \\
0.829\end{array}$ & 0.538 & 0.746 \\
\hline Empathy & $\begin{array}{l}\text { EMP1 } \\
\text { EMP2 } \\
\text { EMP3 } \\
\text { EMP4 }\end{array}$ & $\begin{array}{l}0.887 \\
0.688 \\
0.720 \\
0.751\end{array}$ & 0.602 & 0.780 \\
\hline $\begin{array}{l}\text { Website Design } \\
\text { Quality }\end{array}$ & $\begin{array}{l}\text { WEB1 } \\
\text { WEB2 } \\
\text { WEB3 } \\
\text { WEB4 }\end{array}$ & $\begin{array}{l}0.808 \\
0.817 \\
0.826 \\
0.803\end{array}$ & 0.631 & 0.862 \\
\hline $\begin{array}{l}\text { Customer } \\
\text { Satisfaction }\end{array}$ & $\begin{array}{l}\text { SAT1 } \\
\text { SAT2 } \\
\text { SAT3 } \\
\text { SAT4 } \\
\text { SAT5 }\end{array}$ & $\begin{array}{l}0.890 \\
0.771 \\
0.823 \\
0.748 \\
0.870\end{array}$ & 0.547 & 0.817 \\
\hline $\begin{array}{l}\text { Repurchase } \\
\text { Intention }\end{array}$ & $\begin{array}{l}\text { REP1 } \\
\text { REP2 } \\
\text { REP3 } \\
\text { REP4 } \\
\text { REP5 }\end{array}$ & $\begin{array}{l}0.692 \\
0.766 \\
0.812 \\
0.709 \\
0.849\end{array}$ & 0.522 & 0.772 \\
\hline
\end{tabular}


Gadjah Mada International Journal of Business - May-August, Vol. 21, No. 2, 2019

Table 2. T-Value of Each Dimensions (Asian Continent)

\begin{tabular}{cccc}
\hline Relationship & T-Value & Sig.Value & Conclusion \\
\hline Reliability $\rightarrow$ Service Quality & 3.576 & 0.000 & Significant \\
Responsiveness $\rightarrow$ Service Quality & 5.061 & 0.000 & Significant \\
Assurance $\rightarrow$ Service Quality & 6.980 & 0.000 & Significant \\
Tangible $\rightarrow$ Service Quality & 2.598 & 0.001 & Significant \\
Empathy $\rightarrow$ Service Quality & 3.017 & 0.000 & Significant \\
\hline
\end{tabular}

Table 3. Discriminant Validity Analysis (Asian Continent)

\begin{tabular}{ccccccccc}
\hline & WEB & ASS & REL & RES & TAN & EMP & SAT & REP \\
\hline WEB & 0.817 & & & & & & & \\
ASS & 0.715 & 0.798 & & & & & & \\
REL & 0.408 & 0.536 & 0.903 & & & & & \\
RES & 0.457 & 0.509 & 0.371 & 0.765 & & & & \\
TAN & 0.639 & 0.690 & 0.546 & 0.734 & 0.781 & & & \\
EMP & 0.576 & 0.412 & 0.427 & 0.615 & 0.593 & 0.774 & & \\
SAT & 0.642 & 0.688 & 0.594 & 0.490 & 0.406 & 0.618 & 0.809 & \\
REP & 0.713 & 0.630 & 0.723 & 0.697 & 0.512 & 0.583 & 0.668 & 0.861 \\
\hline
\end{tabular}

Table 4. R-squared (Asian Continent)

\begin{tabular}{cc}
\hline Variables & $\begin{array}{c}\text { R-squared } \\
\text { Value }\end{array}$ \\
\hline $\begin{array}{c}\text { Customer } \\
\text { Satisfaction } \\
\text { Repurchase } \\
\text { Intention }\end{array}$ & 0.556 \\
\hline
\end{tabular}


Table 5. Path Coefficient Analysis (Asian Continent)

\begin{tabular}{cccc}
\hline Relationships & T-Value & Sig.Value & Conclusions \\
\hline $\begin{array}{c}\text { Website Design Quality } \rightarrow \\
\text { Customer Satisfaction } \\
\text { Service Quality } \rightarrow\end{array}$ & 3.045 & 0.001 & Signficant \\
$\quad$ Customer Satisfaction \\
$\begin{array}{c}\text { Customer Satisfaction } \rightarrow \\
\text { Repurchase Intention }\end{array}$ & 4.715 & 0.000 & Signficant \\
$\begin{array}{c}\text { Website Design Quality } \rightarrow \\
\text { Repurchase Intention } \\
\text { Service Quality } \rightarrow\end{array}$ & 3.418 & 0.001 & Signficant \\
Repurchase Intention & 5.598 & 0.000 & Signficant \\
\hline
\end{tabular}

Table 6. Mediation Analysis (Asian Continent)

\begin{tabular}{cccc}
\hline Relationships & T-Value & Sig.Value & Conclusions \\
\hline $\begin{array}{c}\text { Website Design } \rightarrow \text { Repurchase } \\
\text { Intention }\end{array}$ & 3.418 & 0.001 & \\
$\begin{array}{c}\text { Website Design Quality } \rightarrow \\
\text { Customer Satisfaction } \\
\rightarrow \text { Repurchase Intention }\end{array}$ & 3.581 & 0.001 & Partial Mediation \\
$\begin{array}{c}\text { Service Quality } \rightarrow \text { Repurchase } \\
\text { Intention }\end{array}$ & 5.598 & 0.000 & \\
$\begin{array}{c}\text { Service Quality } \rightarrow \text { Customer } \\
\text { Satisfaction } \rightarrow \text { Repurchase } \\
\text { Intention }\end{array}$ & 6.174 & 0.000 & \\
\hline \begin{tabular}{c} 
Partial Mediation \\
\hline
\end{tabular} & & & \\
\hline
\end{tabular}




\section{Australian Continent}

Out of the 250 questionnaires distributed to the respondents living on the Australian continent, a total of 237 were filled out and returned, thus generating a response rate of 94.8 percent. After further analysis, it is concluded that all questionnaires were usable, thus enabling the data to be processed in this research. In terms of the profile of the respondents, a total of 237 of those participating in this research originate from six cities located on the Australian continent, namely Adelaide, Sydney, Gold Coast, Melbourne, Perth, and Brisbane. In terms of respondents' gender, a total of 185 respondents $(78.05 \%)$ were male, while the 52 remaining respondents $(21.95 \%)$ were female. Furthermore, a total of 23 respondents had engaged in purchasing activities between one and seven times through an e-commerce website during the last six months, a total of 199 respondents engaged in purchasing activities eight to fourteen times through an e-commerce website during the last six months, while a total of 15 respondents engaged in purchasing activities more than 15 times through an e-commerce website during the last six months.

Similar to what has been explained in the previous section of this paper where the authors conducted an analysis regarding the data collected from respondents living or originating from the Asian continent, in this section, before analyzing the relationships between variables (inner model analysis), the analysis of service quality dimensions and the outer model analysis need to be conducted in order to ensure the validity and the reliability of the dimensions, variables, and the model. As for the criteria required to be fulfilled by each dimension, indicator, and variable in order for the model to establish the validity and reliability of the model, several criteria that are required to be assessed are actually the same criteria that have been used to measure the service quality dimension and the outer model measurement of the data gathered from Asia in the previous section.

Table 7. Service Quality Dimensions and Outer Model Analysis (Australian Continent)

\begin{tabular}{llccc}
\hline Dimensions & Items & Factor Loadings & AVE & $\begin{array}{l}\text { Composite } \\
\text { Reliability }\end{array}$ \\
\hline \multirow{2}{*}{ Reliability } & REL1 & 0.651 & & \\
& REL2 & 0.809 & 0.530 & 0.786 \\
& REL3 & 0.845 & & \\
& REL4 & 0.792 & & \\
& RES1 & 0.772 & & 0.852 \\
& RES2 & 0.901 & 0.649 &
\end{tabular}


Table 7. Continued

\begin{tabular}{|c|c|c|c|c|}
\hline Dimensions & Items & Factor Loadings & AVE & $\begin{array}{l}\text { Composite } \\
\text { Reliability }\end{array}$ \\
\hline \multirow{4}{*}{ Assurance } & ASS1 & 0.573 & \multirow{4}{*}{0.547} & \multirow{4}{*}{0.798} \\
\hline & ASS2 & 0.748 & & \\
\hline & ASS3 & 0.888 & & \\
\hline & ASS4 & 0.806 & & \\
\hline \multirow{4}{*}{ Tangible } & TAN1 & 0.832 & \multirow{4}{*}{0.552} & \multirow{4}{*}{0.801} \\
\hline & TAN2 & 0.756 & & \\
\hline & TAN3 & 0.894 & & \\
\hline & TAN4 & 0.642 & & \\
\hline \multirow{4}{*}{ Empathy } & EMP1 & 0.790 & \multirow{4}{*}{0.528} & \multirow{4}{*}{0.803} \\
\hline & EMP2 & 0.816 & & \\
\hline & EMP3 & 0.702 & & \\
\hline & EMP4 & 0.857 & & \\
\hline \multirow{4}{*}{$\begin{array}{l}\text { Website } \\
\text { Design } \\
\text { Quality }\end{array}$} & WEB1 & 0.761 & \multirow{4}{*}{0.601} & \multirow{4}{*}{0.749} \\
\hline & WEB2 & 0.752 & & \\
\hline & WEB3 & 0.818 & & \\
\hline & WEB4 & 0.689 & & \\
\hline \multirow{5}{*}{$\begin{array}{l}\text { Customer } \\
\text { Satisfaction }\end{array}$} & SAT1 & 0.774 & \multirow{5}{*}{0.526} & \multirow{5}{*}{0.731} \\
\hline & SAT2 & 0.723 & & \\
\hline & SAT3 & 0.761 & & \\
\hline & SAT4 & 0.707 & & \\
\hline & SAT5 & 0.844 & & \\
\hline \multirow{5}{*}{$\begin{array}{l}\text { Repurchase } \\
\text { Intention }\end{array}$} & REP1 & 0.893 & \multirow{5}{*}{0.549} & \multirow{5}{*}{0.815} \\
\hline & REP2 & 0.713 & & \\
\hline & REP3 & 0.864 & & \\
\hline & REP4 & 0.790 & & \\
\hline & REP5 & 0.758 & & \\
\hline
\end{tabular}


Gadjah Mada International Journal of Business - May-August, Vol. 21, No. 2, 2019

Table 8. T-Value of Each Dimensions (Australian Continent)

\begin{tabular}{cccc}
\hline Relationship & T-Value & Sig.Value & Conclusion \\
\hline Reliability $\rightarrow$ Service Quality & 4.127 & 0.000 & Significant \\
Responsiveness $\rightarrow$ Service Quality & 3.498 & 0.000 & Significant \\
Assurance $\rightarrow$ Service Quality & 3.909 & 0.000 & Significant \\
Tangible $\rightarrow$ Service Quality & 4.124 & 0.000 & Significant \\
Empathy $\rightarrow$ Service Quality & 3.596 & 0.000 & Significant \\
\hline
\end{tabular}

Table 9. Discriminant Validity Analysis (Australian Continent)

\begin{tabular}{lllllllll}
\hline & WEB & ASS & REL & RES & TAN & EMP & SAT & REP \\
\hline WEB & 0.934 & & & & & & & \\
ASS & 0.546 & 0.838 & & & & & & \\
REL & 0.714 & 0.478 & 0.817 & & & & & \\
RES & 0.586 & 0.598 & 0.776 & 0.854 & & & & \\
TAN & 0.748 & 0.634 & 0.493 & 0.467 & 0.812 & & & \\
EMP & 0.406 & 0.714 & 0.724 & 0.539 & 0.680 & 0.769 & & \\
SAT & 0.649 & 0.728 & 0.470 & 0.719 & 0.540 & 0.696 & 0.736 & \\
REP & 0.650 & 0.483 & 0.555 & 0.608 & 0.632 & 0.542 & 0.671 & 0.893 \\
\hline
\end{tabular}

Based on the results of the data analysis presented on Tables 8,9,10, and 11, it can be concluded that all dimensions, indicators and variables have fulfilled all of the criteria set out in this study. Therefore, the inner model analysis can be conducted afterwards in order to determine the relationships between variables studied in this research.

After completing the outer model analysis, the inner model analysis is conducted on the data and the model in order to determine the relationship between variables. Furthermore, mediating analysis is also conducted in this research in order to determine whether variable customer satisfaction does not mediate, partially mediates, or fully mediates the relationship between website design quality and repurchase intention, and between service quality and repurchase intention. Moreover, data generated from the inner model analysis will be used as a benchmark to determine whether the hypotheses posited in 
this research are supported or rejected. Based on the results generated during the PLS-SEM analysis, it can be concluded that both website design quality ( $\mathrm{t}$-value $=$ $2.498)$ and service quality ( $\mathrm{t}$-value $=4.873$ ) have a positive effect on repurchase intention, while customer satisfaction partially mediates the effect of website design quality $(\mathrm{t}$-value $=3.376)$ and service quality $(\mathrm{t}$ value $=4.619)$ on repurchase intention. Moreover, the results of the r-squared value generated in this analysis show that variable customer satisfaction and repurchase intention have a r-squared value of 0.521

Table 10. R-squared (Australian Continent)

\begin{tabular}{cc}
\hline Variables & $\begin{array}{c}\text { R-squared } \\
\text { Value }\end{array}$ \\
\hline Customer Satisfaction & 0.521 \\
Repurchase Intention & 0.739 \\
\hline
\end{tabular}

and 0.739 respectively. Based on these results, it can be concluded that variable customer satisfaction is explained by variable website design quality and service quality by 52.1 percent, while variable repurchase intention is explained by the variables discussed in this research by 73.9 percent.

Furthermore, path coefficient analysis is conducted not only in order to know the relationship between variables, but also to know whether the hypotheses proposed in this research are supported or rejected. The results generated in the path coefficient analysis show that the t-value of all hypotheses exceed the cut-off t-value of 1.96. Therefore, based on these results, it can be concluded that for the Australian continent, all hypotheses in this research are supported. After conducting the analysis on the data gathered from the respondents living on the Australian continent, the author then proceeded with the analysis of the data gathered from the respondents living on the European continent.

Table 11. Path Coefficient Analysis (Australian Continent)

\begin{tabular}{cccc}
\hline Relationships & T-Value & Sig.Value & Conclusions \\
\hline $\begin{array}{c}\text { Website Design Quality } \\
\rightarrow \text { Customer Satisfaction } \\
\text { Service Quality } \rightarrow\end{array}$ & 2.685 & 0.001 & Signficant \\
Customer Satisfaction & 3.712 & 0.000 & Signficant \\
$\begin{array}{c}\text { Customer Satisfaction } \rightarrow \\
\text { Repurchase Intention }\end{array}$ & 3.491 & 0.000 & Signficant \\
$\begin{array}{l}\text { Website Design Quality } \\
\text { Repurchase Intention } \\
\text { Service Quality } \rightarrow\end{array}$ & 2.498 & 0.003 & Signficant \\
Repurchase Intention & 4.873 & 0.000 & Signficant \\
\hline
\end{tabular}


Gadjah Mada International Journal of Business - May-August, Vol. 21, No. 2, 2019

Table 12. Mediation Analysis (Australian Continent)

\begin{tabular}{cccc}
\hline Relationships & T-Value & Sig.Value & Conclusions \\
\hline $\begin{array}{c}\text { Website Design Quality } \rightarrow \text { Repurchase } \\
\text { Intention }\end{array}$ & 2.498 & 0.003 & Partial \\
$\begin{array}{c}\text { Website Design Quality } \rightarrow \text { Customer } \\
\text { Satisfaction } \rightarrow \text { Repurchase Intention } \\
\text { Service Quality } \rightarrow \text { Repurchase } \\
\text { Intention }\end{array}$ & 3.376 & 0.000 & Mediation \\
$\begin{array}{c}\text { Service Quality } \rightarrow \text { Customer } \\
\text { Satisfaction } \rightarrow \text { Repurchase Intention }\end{array}$ & 4.873 & 0.000 & Partial \\
\hline
\end{tabular}

\section{European Continent}

Out of the 250 questionnaires distributed to the respondents living on the Australian continent, a total of 243 were filled out and returned, thus generating a response rate of 97.2 percent. After further analysis, it is concluded that all questionnaires are usable, thus enabling the data to be processed in this research. In terms of the profile of the respondents, a total of 243 of those participating in this research originate from nine countries located on the European continent, namely Denmark, Italy, France, England (UK), Scotland (UK), Netherlands, Germany, Spain, and Sweden. In terms of respondents' gender, a total of 133 respondents (54.73\%) were male, while the 110 remaining respondents (45.27\%) were female. Furthermore, a total of 6 respondents engaged in purchasing activities one to seven times through an ecommerce website during the last six months, a total of 149 respondents engaged in purchasing activities eight to fourteen times through an e-commerce website during the last six months, while a total of 88 respondents engaged in purchasing activities more than 15 times through an e-commerce website during the last six months.

As for the criteria required to be fulfilled by each dimension, indicator, and variable in order to establish the validity and reliability of the model, several criteria which are required to be assessed are actually the same criteria that have been used to measure the service quality dimension and the outer model measurement of the data gathered from the Australian continent in the previous section. Based on the results of the data analysis presented on Tables 15,16,17, and 18, it can be concluded that all dimensions, indicators, and variables have fulfilled all of the outer model criteria set out in this study. Therefore, inner model analysis can be conducted in order to determine the relationships between variables included in this research. 
Table 13. Service Quality Dimensions and Outer Model Analysis (European Continent)

\begin{tabular}{|c|c|c|c|c|}
\hline Dimensions & Items & Factor Loadings & AVE & Composite Reliability \\
\hline Reliability & $\begin{array}{l}\text { REL1 } \\
\text { REL2 } \\
\text { REL3 } \\
\text { REL4 }\end{array}$ & $\begin{array}{l}0.541 \\
0.898 \\
0.753 \\
0.705\end{array}$ & 0.512 & 0.741 \\
\hline Responsiveness & $\begin{array}{l}\text { RES1 } \\
\text { RES2 } \\
\text { RES3 } \\
\text { RES4 }\end{array}$ & $\begin{array}{l}0.743 \\
0.845 \\
0.823 \\
0.810\end{array}$ & 0.597 & 0.819 \\
\hline Assurance & $\begin{array}{l}\text { ASS1 } \\
\text { ASS2 } \\
\text { ASS3 } \\
\text { ASS4 }\end{array}$ & $\begin{array}{l}0.693 \\
0.658 \\
0.835 \\
0.769\end{array}$ & 0.526 & 0.759 \\
\hline Tangible & $\begin{array}{l}\text { TAN1 } \\
\text { TAN2 } \\
\text { TAN3 } \\
\text { TAN4 }\end{array}$ & $\begin{array}{l}0.803 \\
0.714 \\
0.855 \\
0.832\end{array}$ & 0.602 & 0.833 \\
\hline Empathy & $\begin{array}{l}\text { EMP1 } \\
\text { EMP2 } \\
\text { EMP3 } \\
\text { EMP4 }\end{array}$ & $\begin{array}{l}0.858 \\
0.890 \\
0.821 \\
0.836\end{array}$ & 0.653 & 0.867 \\
\hline $\begin{array}{l}\text { Website } \\
\text { Design } \\
\text { Quality }\end{array}$ & $\begin{array}{l}\text { WEB1 } \\
\text { WEB2 } \\
\text { WEB3 } \\
\text { WEB4 }\end{array}$ & $\begin{array}{l}0.867 \\
0.720 \\
0.835 \\
0.754\end{array}$ & 0.546 & 0.782 \\
\hline $\begin{array}{l}\text { Customer } \\
\text { Satisfaction }\end{array}$ & $\begin{array}{l}\text { SAT1 } \\
\text { SAT2 } \\
\text { SAT3 } \\
\text { SAT4 } \\
\text { SAT5 }\end{array}$ & $\begin{array}{l}0.658 \\
0.833 \\
0.890 \\
0.846 \\
0.858\end{array}$ & 0.581 & 0.843 \\
\hline $\begin{array}{l}\text { Repurchase } \\
\text { Intention }\end{array}$ & $\begin{array}{l}\text { REP1 } \\
\text { REP2 } \\
\text { REP3 } \\
\text { REP4 } \\
\text { REP5 }\end{array}$ & $\begin{array}{l}0.769 \\
0.755 \\
0.792 \\
0.804 \\
0.710\end{array}$ & 0.555 & 0.799 \\
\hline
\end{tabular}


Gadjah Mada International Journal of Business - May-August, Vol. 21, No. 2, 2019

Table 14. T-Value of Each Dimensions (European Continent)

\begin{tabular}{cccc}
\hline Relationship & T-Value & Sig.Value & Conclusion \\
\hline Reliability $\rightarrow$ Service Quality & 2.623 & 0.009 & Significant \\
Responsiveness $\rightarrow$ Service Quality & 3.002 & 0.002 & Significant \\
Assurance $\rightarrow$ Service Quality & 2.409 & 0.011 & Significant \\
Tangible $\rightarrow$ Service Quality & 3.507 & 0.000 & Significant \\
Empathy $\rightarrow$ Service Quality & 5.034 & 0.000 & Significant \\
\hline
\end{tabular}

Table 15. Discriminant Validity Analysis (European Continent)

\begin{tabular}{ccccccccc}
\hline & WEB & ASS & REL & RES & TAN & EMP & SAT & REP \\
\hline WEB & 0.871 & & & & & & & \\
ASS & 0.729 & 0.855 & & & & & & \\
REL & 0.547 & 0.646 & 0.780 & & & & & \\
RES & 0.603 & 0.630 & 0.627 & 0.823 & & & & \\
TAN & 0.599 & 0.743 & 0.555 & 0.793 & 0.856 & & & \\
EMP & 0.703 & 0.701 & 0.736 & 0.388 & 0.647 & 0.749 & & \\
SAT & 0.680 & 0.438 & 0.590 & 0.495 & 0.403 & 0.641 & 0.873 & \\
REP & 0.543 & 0.565 & 0.707 & 0.421 & 0.712 & 0.586 & 0.693 & 0.805 \\
\hline
\end{tabular}

After completing the outer model analysis, the inner model analysis is conducted on the data and the model in order to determine the relationship between variables. Furthermore, mediating analysis is also conducted in this research in order to determine whether variable customer satisfaction does not mediate, partially mediates, or fully mediates the relationship between website design quality and repurchase intention, and between service quality and repurchase intention. Moreover, data generated from the inner model analysis will be used as a benchmark to determine whether the hypotheses posited in this research are supported or rejected. Based on the results generated during the
PLS-SEM analysis, it can be concluded that both website design quality ( $\mathrm{t}$-value $=$ $2.714)$ and service quality $(\mathrm{t}$-value $=3.190)$ have a positive effect on repurchase intention, while customer satisfaction partially mediates the effect of website design quality ( $\mathrm{t}$-value $=3.053)$ and service quality $(\mathrm{t}-$ value $=3.566$ ) on repurchase intention. Meanwhile, the results of the r-squared value generated in this analysis, show that customer satisfaction and repurchase intention have a r-squared value of 0.475 and 0.718 respectively. Based on these results, it can be concluded that customer satisfaction is explained by website design quality and service quality by 47.5 percent, while repurchase intention is explained by the 
variables discussed in this research by 71.8 percent.

Furthermore, path coefficient analysis is conducted not only in order to know the relationship between variables, but also to know whether the hypotheses proposed in this research are supported or rejected.

Table 16. R-squared (European Continent)

\begin{tabular}{cc}
\hline Variables & $\begin{array}{c}\text { R-squared } \\
\text { Value }\end{array}$ \\
\hline Customer Satisfaction & 0.475 \\
Repurchase Intention & 0.718 \\
\hline
\end{tabular}

Furthermore, path coefficient analysis is conducted not only in order to know the relationship between variables, but also to know whether the hypotheses proposed in this research are supported or rejected. The results generated by the path coefficient analysis show that the t-value of all hypotheses exceeds the cut-off $t$-value of 1.96. Therefore, it can be concluded that for the European continent, all hypotheses in this research are supported. After conducting the analysis on the data gathered from the respondents living on the European continent, the author then proceeded with the analysis of the data gathered from the respondents living on the North and South American continents.

Table 17. Path Coefficient Analysis (European Continent)

\begin{tabular}{cccc}
\hline Relationships & T-Value & Sig.Value & Conclusions \\
\hline $\begin{array}{c}\text { Website Design Quality } \rightarrow \text { Customer } \\
\text { Satisfaction }\end{array}$ & 2.438 & 0.007 & Signficant \\
$\begin{array}{c}\text { Service Quality } \rightarrow \text { Customer Satisfaction } \\
\text { Customer Satisfaction } \rightarrow \text { Repurchase }\end{array}$ & 3.067 & 0.000 & Signficant \\
$\quad$ Intention & 2.690 & 0.003 & Signficant \\
$\begin{array}{c}\text { Website Design Quality } \rightarrow \text { Repurchase } \\
\text { Intention }\end{array}$ & 2.714 & 0.002 & Signficant \\
$\begin{array}{c}\text { Service Quality } \rightarrow \text { Repurchase Intention } \\
\text { R }\end{array}$ & 3.190 & 0.000 & Signficant \\
\hline
\end{tabular}


Table 18. Mediation Analysis (European Continent)

\begin{tabular}{cccc}
\hline Relationships & T-Value & Sig.Value & Conclusions \\
\hline $\begin{array}{c}\text { Website Design Quality } \rightarrow \\
\text { Repurchase Intention }\end{array}$ & 3.190 & 0.000 & \\
$\begin{array}{c}\text { Website Design Quality } \rightarrow \\
\text { Customer Satisfaction } \\
\rightarrow \text { Repurchase Intention } \\
\quad \text { Service Quality } \rightarrow\end{array}$ & 3.053 & 0.000 & Partial Mediation \\
$\begin{array}{c}\text { Repurchase Intention } \\
\text { Service Quality } \rightarrow\end{array}$ & 3.190 & 0.000 & \\
$\begin{array}{c}\text { Customer Satisfaction } \rightarrow \\
\text { Repurchase Intention }\end{array}$ & 3.566 & 0.000 & Partial Mediation \\
\hline
\end{tabular}

\section{North and South American Continents}

From a total of 250 questionnaires distributed to the respondents living in North and South American continents, a total of 189 were filled and returned, thus generating a response rate of 75.6 percent. After further analysis was conducted, it has been concluded that all questionnaires were usable, thus enabling the data to be processed in this research. In terms of the profile of the respondents, a total of 189 participating in this research originate from four countries located in North and South America, namely United States of America (U.S.), Argentina, Brazil, and Colombia. In terms of respondents' gender, a total of 127 $(67.19 \%)$ were male, while the remaining 62 respondents $(32.81 \%)$ were female. Furthermore, a total of 14 respondents had engaged in purchasing activities between one to seven times through an e-commerce website during the last six months, a total of 95 respondents had engaged in purchas- ing activities eight to fourteen times through an e-commerce website during the last six months, while a total of 80 respondents had engaged in purchasing activities more than 15 times through an e-commerce website during the last six months.

As for the criteria required to be fulfilled by each dimension, indicator, and variable in order to establish the validity and reliability of the model, several criteria which need to be assessed are actually the same criteria that have been used to measure the service quality dimension and the outer model measurement of the data gathered from Europe in the previous section. Based on the results of the data analysis presented on Tables 22,23,24, and 25, it can be concluded that all dimensions, indicators, and variables have fulfilled all of the outer model criteria set out in this study. Therefore, inner model analysis can be conducted afterwards in order to determine the relationships between variables included in this research. 
Table 19. Outer Model Analysis (American Continent)

\begin{tabular}{|c|c|c|c|c|}
\hline Dimensions & Items & Factor Loadings & AVE & $\begin{array}{l}\text { Composite } \\
\text { Reliability }\end{array}$ \\
\hline Reliability & $\begin{array}{l}\text { REL1 } \\
\text { REL2 } \\
\text { REL3 } \\
\text { REL4 }\end{array}$ & $\begin{array}{l}0.765 \\
0.799 \\
0.732 \\
0.802\end{array}$ & 0.548 & 0.776 \\
\hline Responsiveness & $\begin{array}{l}\text { RES1 } \\
\text { RES2 } \\
\text { RES3 } \\
\text { RES4 }\end{array}$ & $\begin{array}{l}0.816 \\
0.739 \\
0.800 \\
0.843\end{array}$ & 0.571 & 0.806 \\
\hline Assurance & $\begin{array}{l}\text { ASS1 } \\
\text { ASS2 } \\
\text { ASS3 } \\
\text { ASS4 }\end{array}$ & $\begin{array}{l}0.782 \\
0.602 \\
0.809 \\
0.711\end{array}$ & 0.530 & 0.741 \\
\hline Tangible & $\begin{array}{l}\text { TAN1 } \\
\text { TAN2 } \\
\text { TAN3 } \\
\text { TAN4 }\end{array}$ & $\begin{array}{l}0.898 \\
0.834 \\
0.790 \\
0.596\end{array}$ & 0.564 & 0.785 \\
\hline Empathy & $\begin{array}{l}\text { EMP1 } \\
\text { EMP2 } \\
\text { EMP3 } \\
\text { EMP4 }\end{array}$ & $\begin{array}{l}0.614 \\
0.776 \\
0.895 \\
0.826\end{array}$ & 0.587 & 0.773 \\
\hline $\begin{array}{l}\text { Website } \\
\text { Design } \\
\text { Quality }\end{array}$ & $\begin{array}{l}\text { WEB1 } \\
\text { WEB2 } \\
\text { WEB3 } \\
\text { WEB4 }\end{array}$ & $\begin{array}{l}0.596 \\
0.886 \\
0.830 \\
0.869\end{array}$ & 0.563 & 0.759 \\
\hline $\begin{array}{l}\text { Customer } \\
\text { Satisfaction }\end{array}$ & $\begin{array}{l}\text { SAT1 } \\
\text { SAT2 } \\
\text { SAT3 } \\
\text { SAT4 } \\
\text { SAT5 }\end{array}$ & $\begin{array}{l}0.707 \\
0.814 \\
0.756 \\
0.887 \\
0.821\end{array}$ & 0.605 & 0.823 \\
\hline $\begin{array}{l}\text { Repurchase } \\
\text { Intention }\end{array}$ & $\begin{array}{l}\text { REP1 } \\
\text { REP2 } \\
\text { REP3 } \\
\text { REP4 } \\
\text { REP5 }\end{array}$ & $\begin{array}{l}0.798 \\
0.691 \\
0.682 \\
0.843 \\
0.829\end{array}$ & 0.531 & 0.767 \\
\hline
\end{tabular}


Gadjah Mada International Journal of Business - May-August, Vol. 21, No. 2, 2019

Table 20. T-Value of Each Dimensions (American Continent)

\begin{tabular}{cccl}
\hline Relationship & T-Value & Sig.Value & Conclusion \\
\hline Reliability $\rightarrow$ Service Quality & 2.546 & 0.002 & Significant \\
Responsiveness $\rightarrow$ Service Quality & 2.907 & 0.000 & Significant \\
Assurance $\rightarrow$ Service Quality & 2.634 & 0.001 & Significant \\
Tangible $\rightarrow$ Service Quality & 3.003 & 0.000 & Significant \\
Empathy $\rightarrow$ Service Quality & 2.749 & 0.001 & Significant \\
\hline
\end{tabular}

Table 21. Discriminant Validity Analysis (American Continent)

\begin{tabular}{lllllllll}
\hline & WEB & ASS & REL & RES & TAN & EMP & SAT & REP \\
\hline WEB & 0.847 & & & & & & \\
ASS & 0.645 & 0.746 & & & & & \\
REL & 0.693 & 0.712 & 0.792 & & & & & \\
RES & 0.444 & 0.694 & 0.387 & 0.809 & & & & \\
TAN & 0.625 & 0.506 & 0.640 & 0.712 & 0.892 & & & \\
EMP & 0.813 & 0.601 & 0.546 & 0.576 & 0.544 & 0.888 & & \\
SAT & 0.528 & 0.297 & 0.667 & 0.734 & 0.721 & 0.708 & 0.835 & \\
REP & 0.606 & 0.467 & 0.710 & 0.406 & 0.627 & 0.352 & 0.697 & 0.778 \\
\hline
\end{tabular}

After completing the outer model analysis, the inner model analysis is conducted on the data and the model in order to determine the relationship between variables. Furthermore, mediating analysis is also conducted in this research in order to determine whether variable customer satisfaction doesn't mediate, partially mediates, or fully mediates the relationship between website design quality and repurchase intention, and between service quality and repurchase intention. Moreover, data generated from the inner model analysis will be used as a benchmark to determine whether the hypotheses posited in this research are supported or rejected. Based on the results generated during the PLS-SEM analysis, it can be concluded that both website design quality ( $\mathrm{t}$-value = 4.327) and service quality ( $\mathrm{t}$-value $=2.482$ ) have a positive effect on repurchase intention, while customer satisfaction partially mediates the effect of website design quality $(\mathrm{t}$-value $=3.936)$ and service quality $(\mathrm{t}$ - 
value $=2.997)$ on repurchase intention . Furthermore, the results of the r-squared value generated by this analysis show that variable customer satisfaction and repurchase intention have a r-squared value of 0.648 and 0.823 respectively. Based on these results, it can be concluded that customer

Table 22. R-squared (American Continent)

\begin{tabular}{cc}
\hline Variables & $\begin{array}{c}\text { R-squared } \\
\text { Value }\end{array}$ \\
\hline Customer Satisfaction & 0.648 \\
Repurchase Intention & 0.823 \\
\hline
\end{tabular}

satisfaction is explained by website design quality and service quality by 64.8 percent, while repurchase intention is explained by variables discussed in this research by 82.3 percent.

Furthermore, path coefficient analysis was conducted not only in order to know the relationship between variables, but also to know whether the hypotheses proposed in this research is supported or rejected. Based on the results generated by the path coefficient analysis, it is revealed that all hypotheses have exceeded the cutoff $t$-value of 1.96. Therefore, based on these results, it can be concluded that in North and South American continents, all hypotheses in this research are supported.

\section{Table 23. Path Coefficient Analysis (American Continent)}

\begin{tabular}{cccc}
\hline Relationships & T-Value & Sig.Value & Conclusions \\
\hline $\begin{array}{c}\text { Website Design Quality } \rightarrow \\
\text { Customer Satisfaction } \\
\text { Service Quality } \rightarrow \text { Customer } \\
\text { Satisfaction }\end{array}$ & 3.470 & 0.000 & Signficant \\
$\begin{array}{c}\text { Customer Satisfaction } \rightarrow \\
\text { Repurchase Intention }\end{array}$ & 3.140 & 0.001 & Signficant \\
$\begin{array}{c}\text { Website Design Quality } \rightarrow \\
\text { Repurchase Intention }\end{array}$ & 4.327 & 0.008 & Signficant \\
$\begin{array}{c}\text { Service Quality } \rightarrow \text { Repurchase } \\
\text { Intention }\end{array}$ & 2.482 & 0.006 & Signficant \\
\hline
\end{tabular}


Table 24. Mediation Analysis (American Continent)

\begin{tabular}{cccc}
\hline Relationships & T-Value & Sig.Value & Conclusions \\
\hline $\begin{array}{c}\text { Website Design Quality } \rightarrow \\
\text { Repurchase Intention } \\
\text { Website Design Quality } \rightarrow\end{array}$ & 4.327 & 0.000 & \\
$\begin{array}{c}\text { Customer Satisfaction } \rightarrow \text { Repurchase } \\
\text { Intention }\end{array}$ & 3.936 & 0.000 & Partial Mediation \\
$\begin{array}{c}\text { Service Quality } \rightarrow \text { Repurchase } \\
\text { Intention }\end{array}$ & 2.482 & 0.006 & Partial Mediation \\
$\begin{array}{c}\text { Service Quality } \rightarrow \text { Customer } \\
\text { Satisfaction } \rightarrow \text { Repurchase Intention }\end{array}$ & 2.997 & 0.002 & \\
\hline
\end{tabular}

\section{Discussion}

The results of the data analysis show that all hypotheses proposed in this research are supported, regardless of where it was conducted. According to the data gathered from respondents living in Asia, Australia, Europe, and North and South America, all hypotheses are supported meaning that website design quality and service quality have a positive effect on repurchase intention, website design quality and service quality have a positive effect on repurchase intention through customer satisfaction, and customer satisfaction has a positive effect on repurchase intention. Based on these results, it can be concluded that regardless of which continent the study is conducted on, website design quality and service quality play an important role in determining consumers' repurchase intention. The results indicate that, regardless of the continent, both website design quality and service quality play an important, major, and non-exchangeable role in developing or inducing loyalty or repurchase intention in the consumers' minds. As buy- ers and sellers don't interact directly in the e-commerce industry, websites developed by the e-commerce companies around the world serve as an important intermediary which functions as a "bridge" to connect the buyer and the seller, which ultimately allows both parties to interact with each another. Therefore, disruption, error, or any other problems which occur on the website might disrupt or damage any communications that have been established by the buyer, seller, and the e-commerce company itself. This is because through the internet, both buyer and seller are able to interact and conduct e-commerce, either regarding the problems with the prospective seller/buyer that they encounter, or the difficulties that they face regarding the layout, system, or the navigational function on the website. Therefore, it is fully understandable that the results generated by this research find that website design quality has both a positive and significant effect on consumers' repurchase intention, which can be explained by the fact that it plays an important role in mediating or bridging the relationships between both the 
current and prospective buyers and sellers with the e-commerce companies.

However, a difference does exist in terms of the importance of website design quality and service quality in affecting repurchase intention when the results from each continent were compared to each other. In Asia, Australia, and Europe, service quality plays a more important role in determining consumers' repurchase intention. This is indicated by the higher t-value that service quality has in terms of repurchase intention (compared to the t-value that website design quality has in terms of repurchase intention. This result is in line with the previous results of studies conducted by both Zhou et al. (2009), Wilson and Keni (2018) and Bernarto et al. (2019), which also find that service quality plays a more important role in affecting customers' repurchase intention. On the other hand, in North and South America, website design quality plays a more important role in determining consumers' repurchase intention compared to service quality. This was indicated by the higher t-value that website design quality has in terms of repurchase intention, compared to the $t$-value that service quality has in terms of repurchase intention. This result is in line with the previous results of studies conducted by Wilson and Keni (2018) which also find that website design quality plays an important role in affecting customers' repurchase intention.

In the e-commerce industry, as there is no direct or face-to-face interaction between the seller and the buyer, a website acts as a "bridge" which facilitates the communication between the seller and the buyer. Therefore, the design quality of a website can be an important factor which determines whether or not the buyer (or potential buyer) will engage in a purchasing activity from the company. When customers encounter various difficulties while surfing the website, there is a high chance that they will stop surfing, close the page, and start surfing a website developed by another e-commerce company. On the other hand, when customers don't encounter any difficulties while they are surfing on a company's website, there is a high chance that they will continue surfing deeper into the website, and might even buy a product or service from that company. Furthermore, a website which has good design quality can satisfy customers, as they feel that the interactions and communications that they have on the website are "flawless" and "effortless", thus increasing the chance that the customers will re-visit the website, or even buy a product or service from the website again.

Similarly, service quality also plays an important role in determining both customers' satisfaction and repurchase intention. When customers feel that the quality of the service provided by the company is great (and exceeds their expectations), customers will be satisfied, thus increasing the chance that they will engage in more purchasing activities in the future. However, when the quality of the service provided by the company is deemed to have been bad, it will disappoint and dissatisfy customers, thus increasing the chance that customers will not buy a product or service from the company again, and will therefore buy it from another company. Therefore, it can be stated that both website design quality and service quality play an important role in affecting customers' satisfaction, which will ultimately affect consumers' repurchase intention with regard to the company. 


\section{Conclusions and Suggestions}

\section{Conclusions}

Based on the results described and explained in the previous section, it namely Asian Australia, Europe, North and South America, website design quality and service quality play an important role in determining consumers' repurchase intention, either directly or indirectly through customer satisfaction. Furthermore, in the Asian, Australian, and European e-commerce industries, service quality plays a more important role in determining or affecting consumers' repurchase intention, while website design quality plays a more important role in determining or affecting consumers' repurchase intention in the North and South American e-commerce industries.

\section{Managerial Implications}

Based on the conclusions drawn in this research, managers or owners of e-commerce companies conducting business in Asia, Australia, Europe, and North and South America should understand the importance of both website design quality and service quality in bringing success to their companies. This is not only because they can affect people's level of satisfaction with a company, but also because both variables can affect consumers' repurchase intention in the future. E-commerce companies with the ability to develop websites with great quality, along with the company's ability to offer customers a service which can be deemed far better than the competitors and able to serve customers well, have a higher chance of attracting, persuading, and motivating customers to buy a product or ser- vice from the company compared to those which don't have such abilities. Therefore, the companies need to improve the quality of the website that they have developed, and also need to improve the quality of the service that they offer to customers in order to prevent them from buying products/ services from another company, which could be hazardous or disastrous for the company.

Furthermore, this research has generated the results which underline that in Asia, Australia, and Europe, service quality plays a more important in determining consumers' repurchase intention. Therefore, managers or owners of companies conducting a business in the field of e-commerce on those continents are required to pay more attention and make more effort to improve the quality of the service that their companies offer to customers in order to please them and increase the chance of them buying products or services from the same company again. However, the design quality of the website also needs to be taken care of, since the website is the place where the seller and buyer meet for the first time, and the place where the buyer will judge whether or not to buy the product or services from the e-commerce company.

In contrast, the results generated in this research underline that in North and South America, website design quality plays a more important role in determining consumers' repurchase intention compared to service quality. Therefore, managers or owners of companies conducting business in the field of e-commerce on the American continents need to understand that the quality of the website developed by the company can prove essential in de- 
termining customers' satisfaction and repurchase intention. Therefore, managers or owners need to keep improving the technological and visual aspects of their websites, so customers can enjoy visiting and exploring the website, and to ensure that customers won't encounter any error or problem while visiting the website. However, the quality of the service offered by the company also needs attention since it can also determine consumers' repurchase intention with regard to the company in the future

\section{Limitations}

This research has several limitations. First of all, this research analyzes the effect of website design quality and service quality on repurchase intention, either directly or through customer satisfaction. Because there might be some other variables which can affect repurchase intention, the author strongly suggests that in the future research, these other variables should be explored and analyzed. Second, this research has been conducted in the e-commerce industry and the results and conclusions of this research might not be generalizable to other industries. Therefore, it is strongly recommended that further research about this topic is conducted in other industries.

\section{References}

Agbor, J. M. 2011. The relationship between customer satisfaction and service quality: A study of three service sectors in Umeå. Thesis. Sweden: Umeå School of Business.

Ahmadi, S., M. R. Karimialavije, N. Malefikar, and S. M. Mohammadi. 2015. The effect of website design quality on the customer's trust and repurchase intention from cosmetic websites. Indian Journal of Fundamental and Applied Life Sciences 5: 4154-4164.

Aksoy, L., T. L. Keiningham, B. Larivière, S. Mithas, F. V. Morgenson III, and A. Yalcin. 2012. The satisfaction, repurchase intention and shareholder value linkage: A longitudinal examination of fixed and firm-specific effects. Paper was presented on the International Conference on Economic Modeling (EcoMod - 2012). Seville, Spain.

Amini, M., and H. Akbari. 2014. Studying effect of site quality on online repurchase intention through satisfaction, trust, and commitment. Indian Journal of Fundamental and Applied Life Sciences 4 (4): 2839-2849.

Barclay, D., C. Higgings, and R. Thompson. 1995. The partial least squares (PLS) approach to casual modeling: Personal computer adoption and use as an illustration. Technology Studies 2 (2): 285-309.

Bernarto, I., M. Wilson, and I. N. Suryawan. 2019. Pengaruh website design quality, service quality, trust dan satisfaction terhadap repurchase intention: Studi kasus pada tokopedia.com. Jurnal Manajemen Indonesia 19 (1): 80-90.

Budiyanti, H., and S. P. S. Patiro. 2018. Perceived fairness, emotions, and intention of fast food chain restaurants customers in Indonesia. Gadjab Mada International Journal of Business 20 (2): 229-253.

Chang, H. H., and S. W. Chen. 2008. The impact of online store environment cues on purchase intention: Trust and perceived risk as a mediator. Online Information Review 32 (6): 818841. https://doi.org/10.1108/14684520810923953. 
Chin, W. W. 1998. The partial least squares approach to structural equation modeling. Modern Methods for Business Research 295 (2): 295-336.

Chinomona, R., and D. Dubihlela. 2014. Does customer satisfaction lead to customer trust, loyalty and repurchase intention of local store brands? The case of Gauteng Province of South Africa. Mediterranean Journal of Social Sciences 5 (9): 23-32.

Chinomona, R., and M. Sandada. 2013. Customer satisfaction, trust and loyalty as predictors of customer intention to re-purchase South African retailing industry. Mediterranean Journal of Social Sciences 4 (14): 437-446.

Chowdhary, N., and M. Prakash. 2007. Prioritizing service quality dimensions. Managing Service Quality 17 (5): 493-509.

Corbitt, B., T. Thanasankit, and H. Yi. 2003. Trust and e-commerce: A study of consumer perceptions. Electronic Commerce Research and Applications 2 (3): 203-215.

Cronin, J. J., and S. A. Taylor. 1992. Measuring service quality: A reexamination and extension. Journal of Marketing 56 (3): 55-68.

Cronin, J. J., M. K. Brady, and G. T. M. Hult. 2000. Assessing the effects of quality, value, and customer satisfaction on consumer behavioral intentions in service environments. Journal of Retailing 76 (2): 193-218.

Cyr, D., G. S. Kindra, and S. Dash. 2008. Web site design, trust, satisfaction and e loyalty: The Indian experience. Online Information Review 32 (6): 773-790.

Ebert, T. 2010. Trust as the Key to Loyalty in Business-to-Consumer Exchanges: Trust Bulding Measures in the Banking Industry. Frankfurt/Main: Springer Science and Business Media.

Eroglu, S. A., K. A. Machleit, and L. M. Davis. 2003. Empirical testing of a model of online store atmospherics and shopper responses. Psychology and Marketing 20: 139-150.

Fang, Y., I. Qureshi, H. Sun, P. McCole, E. Ramsey, and K. H. Lim. 2014. Trust, satisfaction, and online repurchase intention: The moderating role of perceived effectiveness of e-commerce institutional mechanisms. MIS Quarterly 38 (2): 407-427.

Fornell, C. 1992. A National customer satisfaction barometer: The Swedish experience. Journal of Marketing 56: 6-21.

Ganiyu, R. A., I. I. Uche, and A. O. Elizabeth. 2012. Is customer satisfaction an indicator of customer loyalty? Australian Journal of Business and Management Research 2 (7): 14-20.

Gefen, D. 2002. Customer loyalty in e-commerce. Journal of the Association for Information Systems 3: 27-51.

Gera, R. 2011. Modelling the service antecedents of favourable and unfavourable behaviour intentions in life insurance services in India: An SEM study. International Journal of Quality and Service Sciences 3 (2): 225-242.

Greising, D. 1994. Quality: How to make it pay. Business Week (August 8): 54-59.

$\mathrm{Ha}, \mathrm{Y}$., and H. Im. 2011. Role of website design quality in satisfaction and word of mouth generation. Journal of Service Management 23 (6): 79-96.

Ha. Y., and H. Im. 2012. Role of web site design quality in satisfaction and word of mouth generation. Journal of Service Management 23 (1): 79 - 96.

Hair, J. F., C. M. Ringle, and M. Sarstedt. 2011. PLS-SEM: Indeed a silver bullet. The Journal of 
Marketing Theory and Practice 19 (2): 139-151.

Hansemark, O. C., and M. Albinson. 2004. Customer satisfaction and retention: The experiences of individual employees. Managing Service Quality 14 (1): 40- 57.

$\mathrm{He}$, Y., and H. Song. 2008. A mediation model of tourists' repurchase intentions for packaged tour services. Journal of Travel Research 47 (3): 317-331.

Henseler, J., C. M. Ringle, and R. R. Sinkovics. 2009. The use of partial least squares path modelling in international marketing. Advances in International Marketing 20: 277-319.

Hussain, K., and M. Rizwan. 2014. Customer loyalty and switching behavior of customer for Pepsi in Pakistan. Journal of Public Administration and Governance 4 (2): 129-145.

Japutra, A., K. Keni, and B. Nguyen. 2015. The impact of brand logo identification and brand logo benefit on Indonesian consumers' relationship quality. Asia-Pacific Journal of Business Administration 7 (3): 237-252.

Jeong, M., H. Oh, and M. Gregoire. 2003. Conceptualizing web site quality and its consequences in the lodging industry. International Journal of Hospitality Management 22 (2): 161-175.

Jia, L., C. Cegielski, and Q. Zhang. 2014. The effect of trust on customers' online repurchase intention in consumer-to-consumer electronic commerce. Journal of Organizational and End User Computing 26 (3): 65-86.

Jiang, P., and Rosenbloom, B. (2005), "Customer intention to return online: price perception, attribute level performance, and satisfaction unfolding over time. European Journal of Marketing (39) (1-2): 150-174.

Kim, Y.P., S. H. Lee, and D. G. Yun. 2004. Integrating current and competitive service quality level analyses for service quality improvement programs. Managing Service Quality 14 (4): 288-296.

Kitchathorn, P. 2009. Factor Influencing Customer Repurchase Intention: An Investigation of Switching Barriers that Influence the Relationship between Satisfaction and Repurchase Intention in the Low Cost airlines Industry in Thailand. School of Business Administration (DBA), University of South Australia, Australia.

Kotler, P. 2002. Principles of Marketing (3 ${ }^{\text {rd }}$ European ed.). Harlow, England, Prentice Hall.

Kotler, P., and K. L. Keller. 2009. Marketing Management (13 ${ }^{\text {th }}$ ed.). Upper Saddle River, NJ: Pearson Prentice Hall.

Lee, H., S. Y. Choi, and Y-S. Kang. 2009. Formation of e-satisfaction and repurchase intention: moderating roles of computer self-efficacy and computer anxiety. Expert Systems with Applications: An International Journal 36 (4): 7848-7859.

Lin, C., and W. Lekhawipat. 2014. Factors affecting online repurchase intention. Industrial Management and Data Systems 114 (4): 597-611.

Magi, A., and C. R. Julander. 1996. Perceived service quality and customer satisfaction in a store performance framework. Journal of Retailing and Consumer Services 3 (1): 33-41.

Malhotra, N. K. 2007. Marketing Research: An Applied Orientation (5 ${ }^{\text {th }}$ ed.). Upper Saddle River, NJ : Pearson Prentice Hall.

McKnight, D. H., V. Choudhury, and C. Kacmar. 2002. Developing and validating trust measures for ecommerce: an integrative typology. Information Systems Research 13 (3): 334-359. 
Mohsan, F., M. M. Nawaz, M. S. Khan, Z. Shaukat, and N. Aslam. 2011. Impact of customer satisfaction on customer loyalty and intentions to switch: Evidence from banking sector of Pakistan. International Journal of Business and Social Science 2 (16): 263-270.

Negi, R. 2009. User's perceived service quality of mobile communications: experience from Ethiopia. International Journal of Quality and Reliability Management 26 (7): 699-711. https:// doi.org/10.1108/02656710910975769.

Oh, J., S. S. Fioritob, H. Cho, and C. F. Hofackerd. 2008. Effects of design factors on store image and expectation of merchandise quality in web-based stores. Journal of Retailing and Consumer Services 15 (4): 237-249.

Oliver, R. I. 1997. Satisfaction: A Behavioral Perspective on the Consumer. New York, NY: McGraw Hill.

Oliver, R. L. 1993. A conceptual model of service quality and service satisfaction: Compatible goals, different concepts. In T. A. Swartz, D. E. Bowen, and S. W. Brown (Ed.), Advances in Services Marketing and Management 2: 65-85.

Parasuraman, A., V. A. Zeithaml, and L. L. Berry. 1985. A conceptual model of service quality and its implications for future research. Journal of Marketing 49: 41-50.

Parasuraman, A., V. A. Zeithaml, and L. L. Berry. 1991. Refinement and reassessment of the SERVQUAL scale. Journal of Retailing 67 (4): 420-450.

Ribbink, D., C. R. van Riel Allard, V. Liljander, and S. Streukens. 2004. Comfort your online customer: Quality, trust, and loyalty on the internet. Managing Service Quality 14 (6): 446456.

Rosenberg, L. J., and J. A. Czepiel. 1984. A marketing approach for customer retention. Journal of Consumer Marketing 1 (2): 45-51.

Rust, R. T., A. J. Zahorik, and T. L. Keiningham. 1995. Return on Quality (ROQ): Making service quality financially accountable. Journal of Marketing 59(2): 58-70.

Samoszuk, S. (n.d.). Service Quality. Retrieved June 11, 2016, from Study.com: http://study.com/ academy/lesson/service-quality-definition-dimensions.html.

Santos, J. 2003. E service quality: a model of virtual service quality dimensions. Managing Service Quality: An International Journal (1):. 3, pp. 233-246.

Schiffman, L. G., and L. L. Kanuk. 2007. Consumer Behavior ( $9^{\text {th }}$ ed.), New Jersey, NJ : Prentice Hall.

Singh, H. 2006. The importance of customer satisfaction in relation to customer loyalty and retention. UCTI Working Paper WP-06- 06 (May). Kuala Lumpur, Malaysia.

Sivadass, E., and J. L. Baker-Prewitt. 2000. An examination of the relationship between service quality, customer satisfaction, and store loyalty. International Journal of Retail and Distribution Management 28 (2): 73-82.

Spreng, R. A., and R. D. Mackoy. 1996. An empirical examination of a model of perceived serviced service quality and satisfaction. Journal of Retailing 72 (2): 201-214.

Sunyasanoa, S., J. Farquhar, and B. Czarnecka. 2013. Consumer's post-purchase evaluation for repurchase intentions of credence products : Empirical evidence from Thailand. Journal of Retailing (76) (2): 193-218. 
Sureshchandar, G. S., C. Rajendran, and R. N. Anantharaman. 2003. Customer perceptions of service quality in the banking sector of a developing economy: A critical analysis. International Journal of Bank Marketing 21 (5): 233-242.

Ueltschy, L. C., M. Laroche, A. Eggert, and U. Bindl. 2007. Service quality and satisfaction: an international comparison of professional services perceptions. Journal of Services Marketing $21(6): 410-423$.

Upamannyu, N. K., C. Glati, A. Chack, and G. Kaur. 2015. The effect of customer trust on customer loyalty and repurchase intention: The moderating influence of perceived CSR. International Journal of Research in IT, Management and Engineering 5 (4): 1-31.

Van Riel, A. C. R., J. Lemmink, S. Streukens and V. Liljander. 2004. Boost customer loyalty with online support: The case of mobile telecoms providers. International Journal of Internet Marketing and Advertising 1 (1): 4-23.

Wilson, N. 2018. The impact of service quality and brand image toward customer loyalty in the Indonesian airlines industry. Jurnal Manajemen Indonesia 18 (3): 222-234.

Wilson, N., and R. Christella. 2019. An empirical research of factors affecting customer satisfaction: A case of the Indonesian e-commerce industry. DeReMa Jurnal Manajemen 14 (1): 2144.

Wilson, N., and K. Keni. 2018. Pengaruh website design quality dan kualitas jasa terhadap repurchase intention : Variabel trust sebagai variabel mediasi. Jurnal Manajemen dan Pemasaran Jasa 11 (2): 291-310.

Wilson, N., and S. T. Makmud. 2018. The impact of brand evaluation, satisfaction, brand relationship and trust to brand loyalty: A case study of the Indonesian smartphone industry. Jurnal Muara Ilmu Sosial, Humaniora, dan Seni 2 (2): 633-649.

Wilson, N., E. Theodorus, and P. Tan. 2018. Analysis of factors influencing green purchase behavior: A case study of the cosmetics industry in Indonesia. Jurnal Muara Ilmu Sosial, Humaniora, dan Seni 2 (1): 453-464.

Wu, C. S., F. F. Cheng, and D. C. Yen. 2008. The atmospheric factors of online storefront environment design: An empirical experiment in Taiwan. Information and Management 45 (5): 493-498.

Yousapronpaiboon, K. 2014. SERVQUAL: Measuring higher education service quality in Thailand. Procedia - Social and Behavioral Sciences 116: 1088-1095.

Zboja, J., and C. Voorhees. 2006. The impact of brand trust and satisfaction on retailer repurchase intentions. Journal of Service Marketing 20 (6): 381-390.

Zeithaml, V. A., A. Parasuraman, and A. Malhotra. 2002. Service quality delivery through web sites: A critical review of extant knowledge. Journal of the Academy of Marketing Science 30 (4): 358-371.

Zhou, T., Y. Lu, and B. Wang. 2009. The relative importance of website design quality and service quality in determining consumers' online repurchase behavior. Information Systems Management 26: 327-337.

Zviran, M., N. Pliskin, and R. Levin. 2005. Measuring user satisfaction and perceived usefulness in the ERP context. Journal of Computer Information Systems (Spring): 43-52. 